\title{
Assistência remota aos docentes: que tipos de serviços podem ser prestados em home office?
}

\author{
Remote assistance to teachers: what types of services can be provided in the home office?
}

\author{
Cibelle da Silva Santiago ${ }^{1(\mathbb{D})}$, Raul Vitor Oliveira Paes ${ }^{2(1)}$ \\ ${ }^{1}$ Universidade Federal da Paraíba (UFPB), Brasil, Doutoranda em Desenvolvimento e Meio Ambiente (UFPB), professora no \\ curso de Secretariado Executivo (UFPB), e-mail: santiago.cibelle@gmail.com \\ ${ }^{2}$ Universidade Estadual do Pará (UEPA), Brasil, Mestre em Gestão Pública (UEPA), Secretário Executivo (UFPA), professor \\ substituto no curso de Secretariado Executivo (UEPA), e-mail: rauloliverpaes@gmail.com
}

\section{RESUMO}

A jornada do docente universitário se assenta em quatro pilares: ensino, pesquisa, extensão e gestão. Em vista disso, tais sustentáculos se materializam em produtos, dentre eles projetos, relatórios, artigos, resumos, ensaios teóricos, produção de material didático, o que pode requerer assessorias específicas para lidar com uma produção acadêmico-universitária extensa. Assim, o objetivo geral deste estudo é verificar se os docentes universitários possuem a necessidade de um assessoramento remoto para suas atividades acadêmicas e administrativas. A abordagem teórica foi centrada no assessoramento virtual e na jornada de trabalho desse professor, sendo que a pesquisa é de abordagem qualitativa, com aplicação de um questionário a 26 docentes de várias partes do Brasil. As técnicas de análise de dados foram a análise de conteúdo e distribuição de frequências. Os resultados mostram que os docentes têm se envolvido com os quatro pilares da academia, sendo ensino e pesquisa os mais destacados e que há possibilidades de contratação de assessoramento virtual para a prestação de serviços acadêmicos, principalmente em gestão/arquivamento de documentos, elaboração/revisão de materiais pedagógicos e gerenciamento de e-mails. Logo, infere-se que esse campo de trabalho remoto pode ser visto como uma possibilidade a ser explorada pelo profissional de secretariado.

Palavras-chave: Jornada docente. Secretariado Executivo. Teletrabalho.

\begin{abstract}
The university professor's journey is based on four pillars: teaching, research, extension and management. Thus, these pillars are materialized in many products, including projects, reports, articles, abstracts, theoretical essays, production of teaching material, which may require specific advice to better deal with such an extensive academic-university production. Thus, the general objective of this study is to verify whether university professors have the need for remote assistance for their academic and administrative activities. The theoretical approach centered on virtual advice and on the university professor's work period, and the research is of a qualitative approach, with the application of a questionnaire to 26 professors from various parts of Brazil. The data analysis techniques were content analysis and frequency distribution. The results show that teachers have been involved with the four pillars of the academy, with teaching and research being the most detached and that there are possibilities for hiring virtual advisory services for academic demands, mainly in document management/filing, preparation/review pedagogical materials and e-mail management. Soon, this field of remote work being a possibility to be explored by the secretarial professional.
\end{abstract}

Keywords: Professor journey. Executive Secretariat. Telework. 


\section{INTRODUÇÃO}

A profissão secretarial, assim como diversas outras, tem se transformado e adquirido novas formas de atuação com o intuito de atender e criar nichos de mercado. Atuar de forma remota por meio de tecnologias digitais é a expectativa e, ao mesmo tempo, realidade de algumas ocupações para as próximas décadas. Considerando tal contexto, pressupõe-se de igual modo a expansão de novas formas de atuação no exercício profissional secretarial e como exemplos disso destacamos o home office, pool, cooperativas e escritórios virtuais (PAES et al., 2015).

Os cursos superiores de Secretariado Executivo, de modo geral, estão organizados para formar profissionais para atuar em quatro áreas, de acordo com as Diretrizes Curriculares Nacionais dos cursos de graduação para a área (BRASIL, 2005), quais sejam: Assessoria, Gestão, Empreendedorismo e Consultoria. E em relação à assessoria, há realidades de atuação tanto presencialmente quanto a distância, por meio de escritórios virtuais ou assessoria remota. Acerca dos escritórios virtuais no contexto secretarial, já existem estudos realizados no Brasil sobre os serviços que são prestados pelos assistentes remotos aos profissionais liberais (MENDONÇA; CAMPOS; SOUZA, 2017; SANTIAGO; PAES, 2017; SILVA; PAES; SANTIAGO, 2019;), nos quais se constatam um esforço no aprofundamento na caracterização dos serviços secretariais que podem ser ofertados a diversos públicos.

Com base em tais informações, é possível que alguns serviços sejam ofertados aos docentes. Porém, nos estudos anteriores, eles não foram identificados. Compreendendo que professores também atuam como gestores acadêmicos, entende-se que eles realizam atividades ligadas ao cargo de gestão que ocupam, em paralelo com o ensino, a pesquisa e à extensão. Assim, a problemática dessa investigação refere-se à ausência de prestação de serviços pelos assistentes remotos aos docentes universitários. Supõem-se que os assistentes remotos não receberam demandas dos docentes e, por isso, eles ainda não são enxergados como um nicho de mercado.

Justifica-se a necessidade desse estudo devido a probabilidade do aumento na quantidade de secretários executivos que têm atuado como assistentes remotos motivados pela flexibilização oriunda da legislação trabalhista, bem como pelo impulsionamento do trabalho remoto provocado pela pandemia da Covid-19, em 2020. Portanto, os docentes universitários podem representar um nicho de mercado a ser explorado pelos assistentes remotos.

Revista Expectativa, Toledo/PR, v.20, n. 2, p. 90-115, abr./jun., 2021. 
Ademais, o assessoramento virtual aos docentes foi apontado como necessidade de pesquisa futura por Silva (2019), de modo que se pondera relevante levantar informações sobre os serviços que podem ser prestados aos professores universitários. Dessa forma, a perguntaproblema desta pesquisa é a seguinte: Existem demandas acadêmicas e administrativas dos docentes universitários para serem assessorados remotamente? Diante disso, este trabalho objetiva verificar se os docentes universitários possuem a necessidade de um assessoramento remoto para suas atividades acadêmicas e administrativas. Os objetivos específicos são: a) elencar as atividades que são realizadas pelos docentes universitários no quadripé universitário; b) identificar o grau de envolvimento dos professores com as atividades de ensino, pesquisa, extensão e gestão, c) mapear os serviços que podem ser prestados aos docentes universitários por meio de assessoria virtual.

Além desta introdução, este trabalho conta com o referencial teórico discutindo a assessoria virtual como uma tendência de atuação para os secretários executivos, bem como da atuação docente universitário no ensino, pesquisa, extensão e gestão acadêmica. Posteriormente, continua-se com a descrição dos procedimentos metodológicos, a análise e discussão dos resultados, finalizando essa investigação científica com as considerações finais e referências utilizadas.

\section{REFERENCIAL TEÓRICO}

\subsection{ASSESSORIA VIRTUAL: UMA TENDÊNCIA NO CONTEXTO BRASILEIRO?}

Os modos diversos de trabalho a distância tem ganhado destaque e protagonismo em, pelo menos, vinte anos (considerando pesquisas relacionadas à temática) dada às novas configurações de relações sociais e tecnológicas impulsionadas pelas Tecnologias Digitais de Informação e Comunicação (BLEYER, 1999; SILVA, 2000; VALÉRIO; TELES JÚNIOR; VIANA MELLO, 2016; SILVA; SANTIAGO; PAES, 2017; DELLAGNELO et al., 2019). Com o aumento da acessibilidade da internet, inclusive, pelas organizações, o trabalho remoto foi se estabelecendo e criando expectativas no âmbito da atuação, antes apenas de forma física e, mais recente, virtual. Sobre isso, Mello (1999) já apontava para a contribuição dos sistemas de informação como uma estratégia para intensificar esse campo de atuação remota, que independe do tamanho da empresa, seja de 20 ou 20.000 funcionários.

Revista Expectativa, Toledo/PR, v.20, n. 2, p. 90-115, abr./jun., 2021. 
A partir do sistema de informação e de comunicação ocupando a distância física entre os funcionários de uma mesma organização e entre funcionários e clientes, verificase a necessidade de se identificar novas fronteiras do que se entende por local de trabalho (MELLO, 1999, p. 9).

No campo secretarial, levando-se em conta o caráter intrínseco e inicial de assessoria da profissão, o assessoramento remoto despontou com maior conhecimento e abrangência nos anos 2000, de modo mais preciso a partir dos anos 2010, o que demandou estudos mais específicos acerca do modo de organização dos serviços, seus públicos e práticas organizacionais (BARROS et al., 2012). De acordo com leituras extraídas de estudos anteriores (NONATO JÚNIOR, 2009; BARROS et al., 2012; MENDONÇA; CAMPOS; SOUZA, 2017; ABREU et al., 2019) e considerando a progressividade dos estudos acerca do trabalho remoto/assessoria virtual, pode-se interpretar a assessoria virtual como um modo de organização de serviços secretariais e organizacionais voltados à assessoria e cuja prestação deles é feita de modo flexível, não sendo necessária a ocorrência em um único lócus de trabalho.

Considerando o contexto secretarial brasileiro, pode-se destacar alguns modos de trabalho flexível/virtual, conforme apresentados por Mello (1999):

Quadro 1 - Modalidades de trabalho remoto

\begin{tabular}{|c|c|}
\hline $\begin{array}{l}\text { a) Escritório em Casa } \\
\text { (Home Office })\end{array}$ & $\begin{array}{l}\text { É quando um compartimento da casa se transforma num escritório, em que o } \\
\text { indivíduo dispõe de infraestrutura básica necessária para o exercício profissional } \\
\text { como computador, telefone, internet, scanner, agenda, entre outros. Fazendo uso das } \\
\text { tecnologias da comunicação, o sujeito transporta as atribuições profissionais das } \\
\text { organizações para dentro da própria casa. Escritório em casa também pode ser } \\
\text { chamado de escritório doméstico, já que as atividades profissionais podem se } \\
\text { combinar com a rotina doméstica. }\end{array}$ \\
\hline $\begin{array}{l}\text { b) Escritório Virtual } \\
\text { (Virtual Office })\end{array}$ & $\begin{array}{l}\text { Diferente do Escritório em Casa ou doméstico, o indivíduo utiliza espaços e lugares } \\
\text { específicos, seja público ou privado, para trabalhar. Eles podem utilizar os próprios } \\
\text { equipamentos ou emprestar/alugar os que estão à disposição nos escritórios virtuais. } \\
\text { Nos escritórios virtuais, os indivíduos prestam serviços remotamente, por meio de } \\
\text { computadores, telefone e internet, porém, esses escritórios não dependem de uma } \\
\text { estrutura física e fixa de uma organização, permitindo que haja uma descentralização } \\
\text { na atuação dos profissionais como assistentes virtuais a partir de uma infraestrutura } \\
\text { conectada por redes virtuais. Então, os escritórios virtuais podem ser localizados ou } \\
\text { originados em hotéis, galerias empresariais, entre outros. }\end{array}$ \\
\hline $\begin{array}{l}\text { c) Negócios em Casa } \\
\text { (Homebased Business) }\end{array}$ & $\begin{array}{l}\text { Os negócios em casa ocorrem quando o sujeito é um empresário e que utiliza das } \\
\text { suas dependências residenciais para desenvolver seus negócios, produtos e serviços, } \\
\text { bem como estruturar a sua base administrativa e financeira. Nesta modalidade, os } \\
\text { negócios são desenvolvidos na própria residência, sem se estabelecer em outros } \\
\text { locais, como ocorre com os escritórios virtuais. A diferença do Home Office para os } \\
\text { Negócios em Casa é que o indivíduo tem vínculo com uma organização e que } \\
\text { transfere a execução do seu trabalho para o ambiente residencial, enquanto nos } \\
\text { Negócios em Casa a estrutura e funcionamento de uma empresa é estabelecida na } \\
\text { própria residência. }\end{array}$ \\
\hline
\end{tabular}

Revista Expectativa, Toledo/PR, v.20, n. 2, p. 90-115, abr./jun., 2021. 


\begin{tabular}{|c|c|}
\hline $\begin{array}{l}\text { d) Teletrabalho } \\
\text { (Telework) }\end{array}$ & $\begin{array}{l}\text { é um conceito plural e que abrange as demais modalidades específicas de trabalho } \\
\text { remoto, já que em todas elas exige a virtualidade na execução do trabalho, mesmo } \\
\text { que o sujeito tenha ou não vínculo com uma organização. O teletrabalho funciona } \\
\text { como uma aproximação das funções de trabalho ao modo de vida das pessoas, } \\
\text { permitindo uma distância física do trabalhador com a organização, mas uma } \\
\text { proximidade no andamento das atividades, visando não comprometer os resultados } \\
\text { esperados. }\end{array}$ \\
\hline $\begin{array}{c}\text { e) Teletrabalhador } \\
\text { (Teleworker, } \\
\text { Telecommuter) }\end{array}$ & $\begin{array}{l}\text { O teletrabalhador é quem faz o teletrabalho, o home office, os escritórios virtuais } \\
\text { funcionarem, pois ele que é o agente de processo da modalidade de teletrabalho. É o } \\
\text { indivíduo que se utiliza de equipamentos para exercer atividades profissionais, } \\
\text { podendo ser sob } 2 \text { perspectivas: Empregado ou profissional liberal. O teletrabalhador } \\
\text { pode estar vinculado a uma organização ou ele mesmo atuar como empresário, } \\
\text { utilizando de telefone, internet e canais digitais para estabelecer a comunicação } \\
\text { virtual, seja com a empresa em que possui vínculo, seja com os seus clientes ou } \\
\text { colaboradores. }\end{array}$ \\
\hline $\begin{array}{l}\text { g) Trabalho Flexível } \\
\text { (Flexible Working) }\end{array}$ & $\begin{array}{l}\text { No teletrabalho pressupõe-se que a orientação seja voltada para o resultado em si, e } \\
\text { não apenas pelo cumprimento da carga horária em locais físico, priorizando a } \\
\text { negociação entre o patrão e o empregado, a organização e os clientes. Na prática, o } \\
\text { trabalho flexível leva em consideração as variáveis físicas de estrutura e de } \\
\text { sistematização da organização como: horário de trabalho, dias de folgas, } \\
\text { cumprimento da jornada de trabalho, tipos de serviços que podem ser prestados à } \\
\text { distância ou presencial, formas de contrato do trabalho, entre outras. Com o trabalho } \\
\text { remoto, a flexibilização permite negociar e combinar a forma como o atendimento } \\
\text { será feito, como os procedimentos serão executados, como os processos serão } \\
\text { planejados e como os resultados serão entregues, indo além das formalidades } \\
\text { clássicas existentes no modo presencial. }\end{array}$ \\
\hline
\end{tabular}

Fonte: adaptado de Mello (1999).

Cada uma delas possui vantagens e desvantagens, que devem ser observadas para a adequada adaptação do profissional da área secretarial. Algumas vantagens podem ser observadas, como exemplo: atuação em outro lugar que não precise ser no trabalho; autonomia e maior organização autônoma do trabalho; redução de custos com transporte e deslocamento; economia de tempo; otimização de processos (ABREU et al., 2019). Por outro lado, algumas desvantagens também podem ser destacadas, dentre elas: a) maior dificuldade na captação e manutenção de clientes; b) barreira cultural e dificuldades de confiança/resistências quanto à aceitação da assessoria virtual; c) diminuição das relações interpessoais; d) determinadas tarefas/processos demandam momentos presenciais (SOUZA; MOREIRA; MARTINS, 2018; ABREU et al., 2019).

A literatura científica verificada sobre o assessoramento virtual também é recente (PAES; SANTIAGO, 2019), porém já é possível notar alguns desdobramentos: a) investigação do trabalho remoto/assessoramento virtual como modo de atuação no campo secretarial (BARROS et al., 2012; PAES et al., 2015; SOUZA, MOREIRA, MARTINS, 2018); b) estudos de viabilidade e implementação de escritórios virtuais (MARREIROS et al., 2016; VALÉRIO et al., 2016); c) modos de adaptação do profissional de secretariado ao trabalho virtual 
(FANZERES; LIMA, 2018); d) diferenças entre o trabalho tradicional e o trabalho flexível de secretariado/assessoria (SILVA; SANTIAGO; PAES, 2017; PAES; SANTIAGO, 2020); e) tipologias/terminologias de serviços prestados pelo trabalho secretarial remoto (ABREU et al., 2019; COSTA; CHIZZONI; VAZ, 2019).

Desse modo, entende-se que temáticas diversas estão sendo desenvolvidas acerca do assessoramento remoto, para melhor compreensão do fenômeno dentro do campo secretarial, o que pode resultar em análises acuradas sobre os limites e possibilidades da atuação remota e flexível pelo profissional de secretariado, indicando o tema de secretariado/assessoramento remoto como uma tendência profissional e de estudos na área. Em especial, alguns trabalhos merecem destaque acerca das classificações de serviços prestados pelo assessoramento virtual, os quais se encontram no Quadro 2:

Quadro 2 - Categorias de serviços secretariais encontrados em estudos teórico-empíricos

\begin{tabular}{|c|c|}
\hline AUTORES/AS & CATEGORIAS \\
\hline Barros et al. (2012) & $\begin{array}{c}\text { serviços administrativos / serviços financeiros/compras / serviços de recursos } \\
\text { humanos. }\end{array}$ \\
\hline $\begin{array}{l}\text { Mendonça; Campos; } \\
\text { Souza (2017) }\end{array}$ & $\begin{array}{c}\text { serviços administrativos / redação de textos profissionais especializados / } \\
\text { assistência e assessoramento / coleta de informações para a concessão de objetivos } \\
\text { e metas da empresa / outros serviços. }\end{array}$ \\
\hline Silva et al. (2017) & Tarefas Burocráticas em Geral / Serviços de Varejo / Serviços Bancários. \\
\hline Paes; Santiago (2019) & $\begin{array}{c}\text { Serviços burocráticos gerais (de secretaria) / Serviços orçamentários, financeiros e } \\
\text { bancários / Serviços de Marketing, Publicidade e Propaganda Serviços contábeis e } \\
\text { cartorários / Serviços administrativos diversos }\end{array}$ \\
\hline
\end{tabular}

Fonte: elaboração própria, com base nos estudos citados acima (2020).

Nota-se que algumas classificações são recorrentes entre as categorias elencadas, especialmente as relacionadas aos serviços administrativos (incluindo os diversos, a exemplo de consultoria e assessoria em eventos), os serviços burocráticos gerais (de secretaria) e os orçamentários/financeiros/bancários, o que reflete na produção de serviços secretariais simples e complexos dada a formação multidisciplinar/interdisciplinar que a área abrange (MENDONÇA; CAMPOS; SOUZA, 2017; PAES; SANTIAGO, 2019), além de incrementos em capacitações específicas para ampliação do mix de serviços.

Importa ressaltar, também, que os estudos elencados no Quadro 1 refletem o contexto de quaisquer organizações de modo geral, porém nenhum deles destaca possibilidades de assessoramento virtual para organizações/demandas acadêmicas/universitárias específicas dos docentes, como assessorias específicas para otimização do trabalho docente, como verificado no tópico a seguir.

Revista Expectativa, Toledo/PR, v.20, n. 2, p. 90-115, abr./jun., 2021. 


\subsection{JORNADA DE TRABALHO DO DOCENTE UNIVERSITÁRIO}

O indivíduo que decide atuar como professor em ambiente universitário apresenta um desejo de ensinar. Segundo Gonçalves (1999), alguns professores escolhem essa profissão por realmente possuírem uma vocação para ensinar, porém, outros querem satisfazer o ego, ou são influenciados a aceitar a oportunidade devido às dificuldades de empregabilidade em outras áreas. Nesse contexto, independente dos motivos que levaram o indivíduo a seguir a carreira docente, propõe aqui abordar um pouco sobre essa jornada.

De acordo com Nóvoa (1999), a gênese da profissão de professor relaciona ele com o saber e as técnicas para o ensino, de modo que o imaginário sobre a função de professor é limitado ao ato de ensinar, elaborar e corrigir provas, preparar materiais didático-pedagógico. No entanto, as atribuições do professor universitário vão além, pois devem contemplar não só o ensino, mas também a pesquisa e a extensão, que devem ser indissociáveis, conforme estabelecido na constituição brasileira (BRASIL, 1988). Assim, o docente universitário deve pautar suas atividades nessas áreas, de modo que elas estejam interligadas. Sobre isso, Marques (2011) resume a prática do ensino, pesquisa e extensão na carreira do professor.

O ensino busca formar profissionais de nível superior com sólida base científica e tecnológica, requeridos pela sociedade, bem como formar pesquisadores. A pesquisa, (estimula a) criação de conhecimento novo, é a atividade que desfruta de maior prestígio no conjunto das atividades desenvolvidas pela universidade; 2 . A extensão busca criar vínculos com o meio onde a universidade está, tornando-a parte deste meio, mediante a aplicação de conhecimentos a situações e demandas específicas (MARQUES, 2011, p. 686) (grifo nosso).

O docente universitário possui a necessidade de desenvolver competências para lecionar e aprimorar suas atividades pedagógicas, com o objetivo de formar profissionais com capacidade crítica e analítica, a partir de uma formação sólida e humanística. "O profissional crítico faz escolhas subsidiado no conhecimento científico, constrói seu conhecimento considerando a diversidade social, cultural, econômica, humana" (TOZETTO, 2010, p. 13).

Ao professor universitário cabe construir novos conhecimentos para disseminar com os alunos a partir da interação entre o ensino, a pesquisa e a extensão que, reconhecendo as contribuições que um dá ao outro, devem ser trabalho de forma indissociável.

O ensino é, provavelmente, o melhor exemplo dessa renovação, à medida que, integrado ao conhecimento produzido através da pesquisa e aos anseios da sociedade considerados nas atividades de extensão, ganha em relevância e significado para a comunidade universitária (MOITA; ANDRADE, 2009, p. 272).

Revista Expectativa, Toledo/PR, v.20, n. 2, p. 90-115, abr./jun., 2021. 
Embora o ensino seja considerado o primeiro passo de um professor na sua jornada acadêmica, comparado às atividades de pesquisa e extensão, visualiza-se um caminho inverso para a geração de novos conhecimentos. Conjectura-se que é na extensão que a comunidade acadêmica enxerga alguns problemas sociais, os quais podem ser solucionados e desmistificados através da pesquisa científica que, por sua vez, se utiliza de métodos para transformar o conhecimento comum em científico, de modo que o conhecimento gerado seja, então, ensinado em sala de aula, pois "não há pesquisa nem extensão universitária que não desemboquem no ensino" (MOITA, ANDRADE, 2009, p. 272).

Para Freire (2003), o ato de ensinar está diretamente relacionado ao saber do professor, de maneira que ele tem que conhecer o conteúdo para poder ensinar. "O professor é um profissional que trabalha com o conhecimento, e, para tanto, necessita ter compromisso com a aprendizagem discente" (MENDES; BACCON, 2015, p. 39787). Já Ens e Donato (2011, p. 83) definem que a "atividade de ensinar realiza-se a partir de conhecimentos específicos e necessários [...] os quais são adquiridos, construídos na formação inicial e na formação que acontece durante toda a vida profissional".

Por fim, Libâneo (2002) destaca que o ensino se refere a uma articulação dinâmica entre o professor e o aluno, que envolve planejar a aula, selecionar e organizar os conteúdos programáticos, criar condições favoráveis de estudo dentro da sala de aula, estimular a curiosidade e criatividade dos alunos, além de programar atividades pedagógicas e visitas técnicas, definir o método de avaliação da aprendizagem.

No que concerne à pesquisa, o professor se debruça sobre os cenários e fenômenos para gerar novos conhecimentos e teorias, por meio de métodos científicos. Por meio da pesquisa científica, os desafios que existem na realidade e no cotidiano devem ser enxergados pelo professor como um obstáculo a serem superados ou solucionados cientificamente. O professor deve elaborar projetos a partir de uma problemática visando buscar soluções por meio de investigações científicas.

No caso da pesquisa, por exemplo, as submissões de projetos são feitas a partir de templates desenhados por fundações de apoio e agências de fomento com várias ferramentas definidas para organizar e mapear o desenvolvimento e realização desses projetos, datas e prazos a serem respeitados desde o início (BARBOSA; MENDONÇA, 2014, p. 136). 
Vê-se que o docente precisa ter um senso investigativo para identificar e delimitar problemáticas de pesquisa, bem como estruturá-las em um documento formal para atender as exigências do órgão onde o projeto será submetido. Com isso, o docente precisa formar uma equipe com outros professores-pesquisadores, juntamente com os estudantes e, portanto, liderálos e gerenciá-los para que o projeto seja executado e finalizado com os resultados esperados.

Já na extensão, o professor elabora um projeto para executar junto à sociedade em que está inserido, sendo outra ação institucional. A partir de problemáticas sociais, ele forma uma equipe para que, "através de projetos sociais, a universidade socializa seu conhecimento e disponibiliza seus serviços, exercendo sua responsabilidade social, ou mesmo sua missão: o compromisso com a melhoria da qualidade de vida dos cidadãos" (NUNES; SILVA, 2011, p. 121). Assim o docente deve observar o mundo ao seu redor e buscar alternativas e métodos para interagir com a sociedade, visando propor a solução de problemas, bem como experimentar as teorias para confirmar ou refutar as hipóteses, a partir das práticas extensionistas. Os atores da universidade devem se colocar à disposição da comunidade, no sentido de dar suporte e assistência, por meio de projetos institucionais para encontrar ou viabilizar soluções e alternativas para os desafios enfrentados pela comunidade.

Normalmente, os projetos de extensão da universidade têm uma duração cerca de 10 meses, os quais precisam ser planejados e executados junto à comunidade público-alvo do projeto. Ao final da execução, o professor deve elaborar o relatório objetivando prestar contas do serviço prestado à sociedade junto à universidade, bem como dos recursos humanos e financeiros utilizados.

Dessa forma, quando as atividades de extensão são realizadas em paralelo às de ensino e pesquisa, o docente tem uma elevada carga de trabalho, o que é considerado um fator limitante para que o docente desenvolva atividades no ensino, junto à pesquisa e extensão (ENUMO, 1996).

Todavia, as atividades do professor vão além do ensino, da pesquisa e da extensão, pois inclui a gestão, corroborando com Perrenoud (2000) que estabelece dez competências do professor e, dentre elas, "participar da administração da escola". Atuar como gestor acadêmico, exige "elaborar, negociar um projeto da instituição; administrar os recursos da escola; coordenar, dirigir uma escola com todos os seus parceiros; organizar e fazer evoluir, no âmbito da escola, a participação dos alunos" (CONCEIÇÃO; SOUSA, 2012, p. 86).

Revista Expectativa, Toledo/PR, v.20, n. 2, p. 90-115, abr./jun., 2021. 
O professor, além de ministrar aulas e desenvolver projetos de pesquisa e extensão, também atua como gestor na instituição, dirigindo, coordenando e organizando processos e pessoas, de modo que é imputado a ele "competências gerenciais que lhes permitam alinhar o conhecimento técnico ao administrativo, além de habilidades de negociação e análise do contexto econômico, político e social” (MIRANDA, 2010, p. 13).

\footnotetext{
Dos professores é esperado não só a contribuição para a ciência, para sua área de estudo, para comunidade ou para sua disciplina; deles também se esperam contribuições para o desempenho global da sua universidade, o que inclui o alcance de índices, metas e posicionamento em rankings de avaliação das mais diversas naturezas (BARBOSA; MENDONÇA, 2014, p. 137).
}

Nesse leque de possibilidades para atuação do docente, cada um traça o seu caminho profissional e objetivos a serem alcançados na carreira. Conjecturamos que, mesmo o ensino sendo a base de atuação do professor, mas há de se cumprir o princípio da indissociabilidade com a pesquisa, extensão e, também, a gestão. Nesse contexto, diversas tarefas precisam ser desempenhadas em cada eixo, de modo que, na maioria das vezes, há uma sobrecarga de trabalho para ele e isso o estimula a ter que escolher dois eixos para focar os seus esforços.

\section{PROCEDIMENTOS METODOLÓGICOS}

Para realização deste trabalho, além do levantamento bibliográfico sobre o tema de interesse, desenvolveu-se pesquisa empírica com abordagem qualitativa, sobre a possibilidade de oferecimento de serviço de assessoramento virtual aos docentes universitários. Quanto aos objetivos, o estudo se caracteriza como descritivo. O levantamento bibliográfico para o aporte teórico se concentrou na busca de artigos científicos publicados no portal de periódicos da Scielo e em revistas especializadas da área de secretariado e afins, além dos anais de eventos técnico-científicos, com os termos de busca "assessoria virtual", "secretário virtual", "secretariado virtual" e "secretariado remoto".

Do levantamento, foram encontrados 4 trabalhos que tratam sobre os serviços prestados pelos assistentes remotos, apresentados no Quadro 1. Para o alcance dos objetivos desta pesquisa, o instrumento utilizado foi o questionário que, de acordo com Ruiz (2008, p. 51), “o informante escreve ou responde por escrito a um elenco de questões cuidadosamente elaboradas". Concernente ao método de abordagem para a coleta de dados é de métodos mistos,

Revista Expectativa, Toledo/PR, v.20, n. 2, p. 90-115, abr./jun., 2021. 
tendo em vista que análises quantitativas como qualitativas serão empregadas em conjunto para melhor compreensão do fenômeno estudo (CRESWELL, 2007).

Para tanto, a coleta de dados foi realizada com o questionário, em que a sua construção se deu a partir de estudos que tratam de serviços ofertados pelo secretariado remoto (BARROS et al., 2012; MENDONÇA; CAMPOS; SOUSA, 2017; PAES et al., 2015; PAES; SANTIAGO, 2019; SILVA; SANTIAGO, PAES, 2017). O questionário foi elaborado com perguntas fechadas e abertas na plataforma do Google Forms, sendo aplicado aos professores dos cursos de Secretariado Executivo de diversas instituições de ensino do Brasil, mesmo os que não são formados em Secretariado, já que o foco está nas atividades do docente e isso não está restrito a uma única formação.

Assim, os dados obtidos foram analisados e comparados à luz da análise de conteúdo, de Bardin (2011), que aponta que nela há a etapa de exploração do material, em que são constituídas categorias de análise para classificação das inferências e conhecimentos obtidos. Neste trabalho, as seguintes categorias de análise foram emergidas: a) perfil dos docentes pesquisados; b) realização de trabalho dos docentes na academia (ou atividades dos docentes); e c) possibilidades de delegação de atividades acadêmicas aos assessores remotos. Além do mais, nas categorias de análise foram aplicadas as técnicas estatísticas de distribuição de frequências absolutas e relativas, para efeitos de comparação dos serviços mais ofertados pelos profissionais.

\section{RESULTADOS E DISCUSSÕES}

O questionário online que foi aplicado aos docentes dos cursos de Secretariado Executivo, de diversas instituições de ensino superior, obteve um retorno de 26 questionários respondidos. O sexo dos respondentes é feminino (19) e masculino (7), com faixa etária compreendida entre 26 a 35 anos e 36 a 45 anos.

Para compreender melhor as atividades desenvolvidas e envolvimento com o quadripé, ensino, pesquisa e extensão, questionou aos docentes acerca do tempo de atuação, conforme apresentado no gráfico 1.

Revista Expectativa, Toledo/PR, v.20, n. 2, p. 90-115, abr./jun., 2021. 
Gráfico 1 - Tempo de atuação como docente universitário

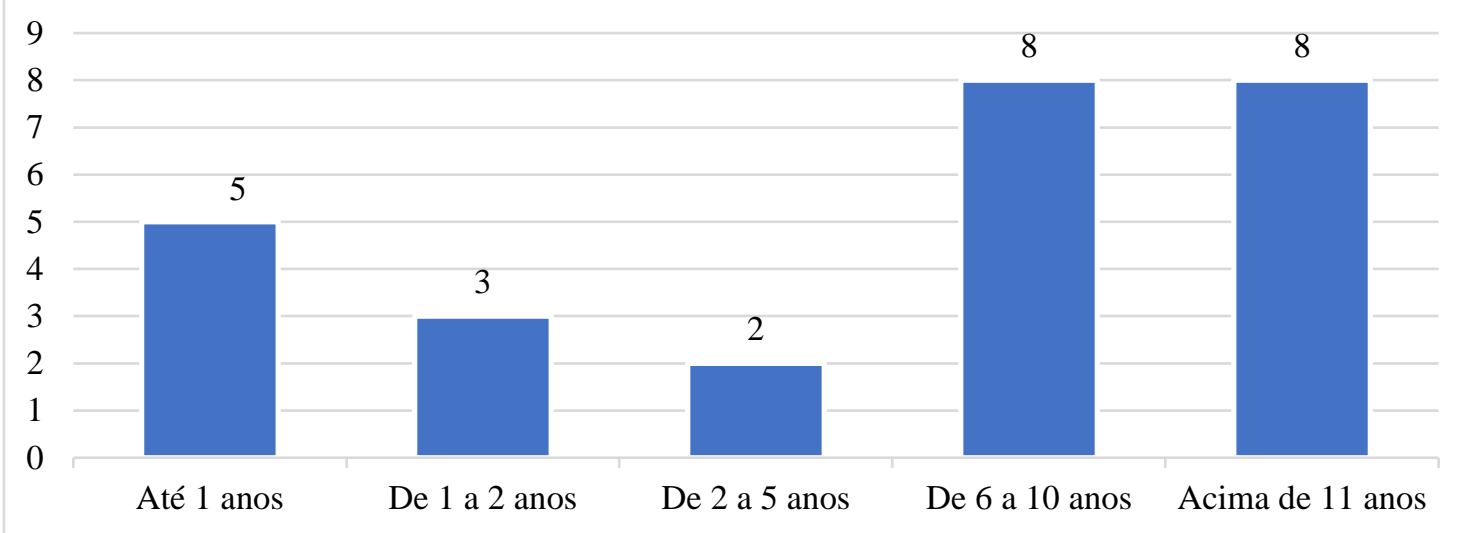

Fonte: dados da pesquisa (2020).

Registra-se que, dentre os respondentes, há um empate acerca do tempo de atuação, entre a duração de 6 a 10 anos e acima de 11 anos ( 8 respostas em cada), o que denota um expressivo tempo de atuação e, consequentemente, maiores possibilidades de experiência em atribuições diversas da docência universitária. Em sequência, 5 dos docentes têm até um ano de atuação. Os 5 docentes que atuam de 1 até 5 anos podem ser considerados jovem-professor ou iniciante que, segundo Feixas (2002), Bozu (2009) e Feldkercher (2013), é aquele que está nos seus primeiros três anos de experiência docente.

Em seguida, no gráfico 2, perguntou-se em quais pilares o professor está diretamente envolvido, se no ensino, na pesquisa, na extensão ou gestão. Esta pergunta permitiu o professor marcar mais de uma opção, em que, naturalmente, todas as respostas de cada eixo ultrapassam 26, já que é possível responder mais de um item. Então, 26 dos respondentes estão envolvidos com o ensino, 21 com a pesquisa, enquanto 14 com extensão e 11 ocupam cargos de gestão concomitantemente ao ensino.

Revista Expectativa, Toledo/PR, v.20, n. 2, p. 90-115, abr./jun., 2021. 
Gráfico 2 - Envolvimento dos professores com o ensino, pesquisa, extensão e gestão

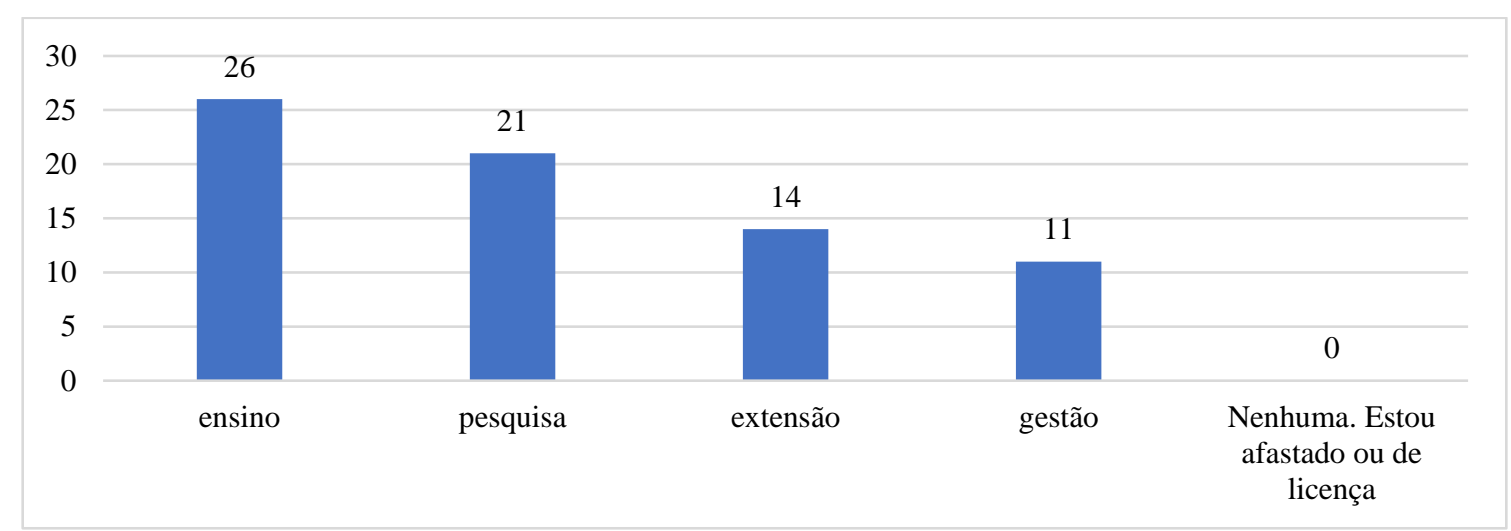

Fonte: dados da pesquisa (2020).

Para Mazzilli (2005), a consecução da associação entre ensino, pesquisa e extensão demanda: a existência de projetos institucionais que anunciem as diretrizes e os compromissos que os orientam e as ações previstas para sua realização; projetos coletivos de trabalho, associando ações acadêmicas e administrativas; práticas de avaliação institucional abrangendo todo o trabalho realizado pela universidade, como instrumento de autoconhecimento institucional; modelos de gestão que possibilitem a participação de todos os segmentos no processo de decisão e de avaliação do trabalho acadêmico; corpo docente com sólida formação científica e pedagógica, organicamente vinculada ao projeto da universidade; e, principalmente, condições materiais para a realização do projeto pretendido.

Como forma de esmiuçar e tentar compreender as atividades específicas em que os docentes estão diretamente envolvidos no ensino, na pesquisa, na extensão e na gestão, os gráficos 3, 4, 5 e 6 posteriores apresentam os resultados.

No gráfico 3, a seguir, têm-se as atividades que são desenvolvidas no ensino, em que 20 docentes atuam em cursos de graduação; 15 orientam estágio supervisionado; enquanto 9 dos respondentes participam de projetos de monitoria. Entendendo que o ensino é a atividade basilar da atuação docente, de modo que a maioria dos respondentes estão ministrando disciplinas, seja na graduação, na pós-graduação ou em cursos técnicos. Em seguida, os respondentes apontaram o seu envolvimento com a orientação de estágio supervisionado, em que a Lei nº 11.788 , de 25 de setembro de 2008 (BRASIL, 2008), estabelece a normatização do estágio dos estudantes e relaciona o ensino e o campo de estágio, visando colocar o aluno em experiência com a prática do seu exercício profissional.

Revista Expectativa, Toledo/PR, v.20, n. 2, p. 90-115, abr./jun., 2021. 
Gráfico 3 - Atividades desenvolvidas no ensino

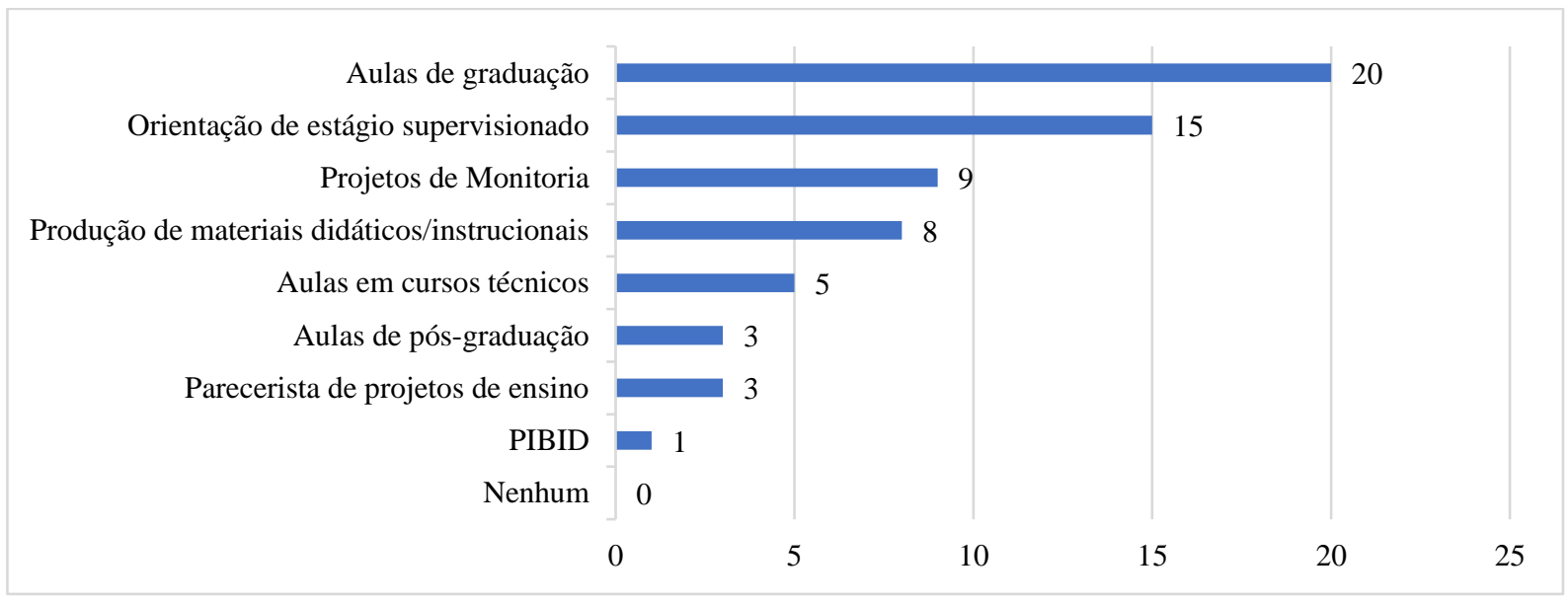

Fonte: dados da pesquisa (2020).

Além do ensino, têm-se as atividades desenvolvidas em torno da pesquisa científica, de modo que 18 docentes apontaram o seu maior envolvimento com a orientação de TCC; 16 estão orientando artigos para publicação em eventos ou em periódicos científicos; e 15 docentes são membros de grupo de pesquisa. Bridi (2004, p. 29) destaca que: [...] "a atividade de pesquisa na graduação é considerada por professores e universitários uma atividade motivadora e muito enriquecedora, que torna a formação mais abrangente e dota os graduandos de maior capacidade de observação e crítica". Demais atividades estão expostas no gráfico 4:

Gráfico 4 - Atividades desenvolvidas na pesquisa

Orientação de TCC

Orientação/Autoria de Artigos para eventos ou periódicos Membro de Grupo de Pesquisa Parecerista de projetos/relatórios de pesquisa Membro de comitê editorial de periódico científico PIBIC/PIVIC Coordenação de Grupos de Pesquisa Nenhum Gestão de Periódico Científico Orientação de Dissertação ou Tese Coordenação de Laboratório

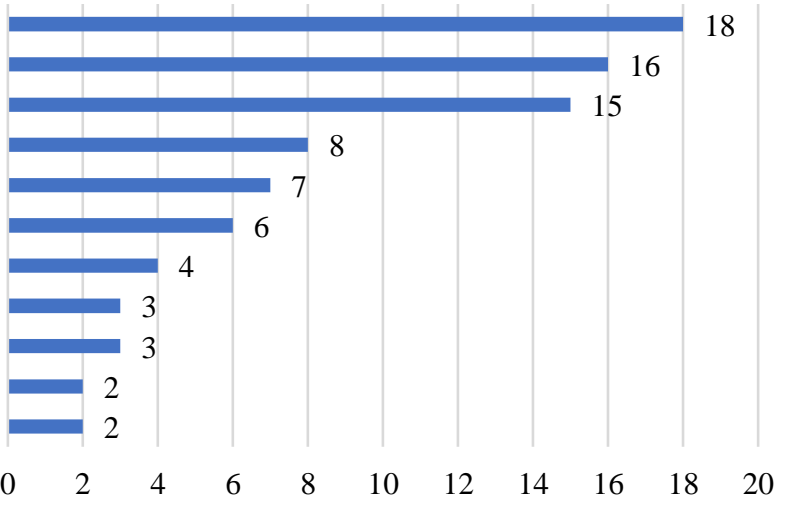

Fonte: dados da pesquisa (2020).

Revista Expectativa, Toledo/PR, v.20, n. 2, p. 90-115, abr./jun., 2021. 
Com menor intensidade e de acordo com o gráfico 4, tem-se o envolvimento de 6 docentes com projetos de PIBIC/PIVIC ${ }^{1}$. Complementa-se que a iniciação científica é a possibilidade de colocar o aluno desde cedo em contato direto com a atividade científica e engajá-lo na pesquisa (BRASIL, 1998, p. 7). Mas, para ser um professor orientador de PIBIC e PIVIC, o docente deve:

[...] possuir experiência compatível com a função de orientador e formador de recursos humanos qualificados e, preferencialmente, estar cadastrado no Diretório dos Grupos de Pesquisa do CNPq, ser pesquisador em regime de trabalho com tempo integral, dedicação exclusiva, com título de doutor ou equivalente, ou, excepcionalmente, mestre, com produção científica, tecnológica ou artístico-cultural, nos últimos 5 (cinco) anos, divulgada nos principais veículos de comunicação da área (BRASIL, 1998, p. 12).

Considerando que $30 \%$ dos respondentes possuem de 1 até 5 anos de atuação docente (gráfico 1), compreende-se que eles ainda não possuem tempo e experiência suficiente para orientar tais projetos, de maneira que eles poderão evoluir gradualmente o caminho da pesquisa com orientações de TCC e artigos científicos para eventos e periódicos.

Adiante, o gráfico 5 traz as atividades desenvolvidas com projetos de extensão, em que 21 professores atuam ministrando oficinas, palestras, cursos livres e cursos de capacitação, 24 professores produzem materiais didáticos e atuam nos projetos de extensão como coordenadores ou apenas membros.

Gráfico 5 - Atividades desenvolvidas na extensão

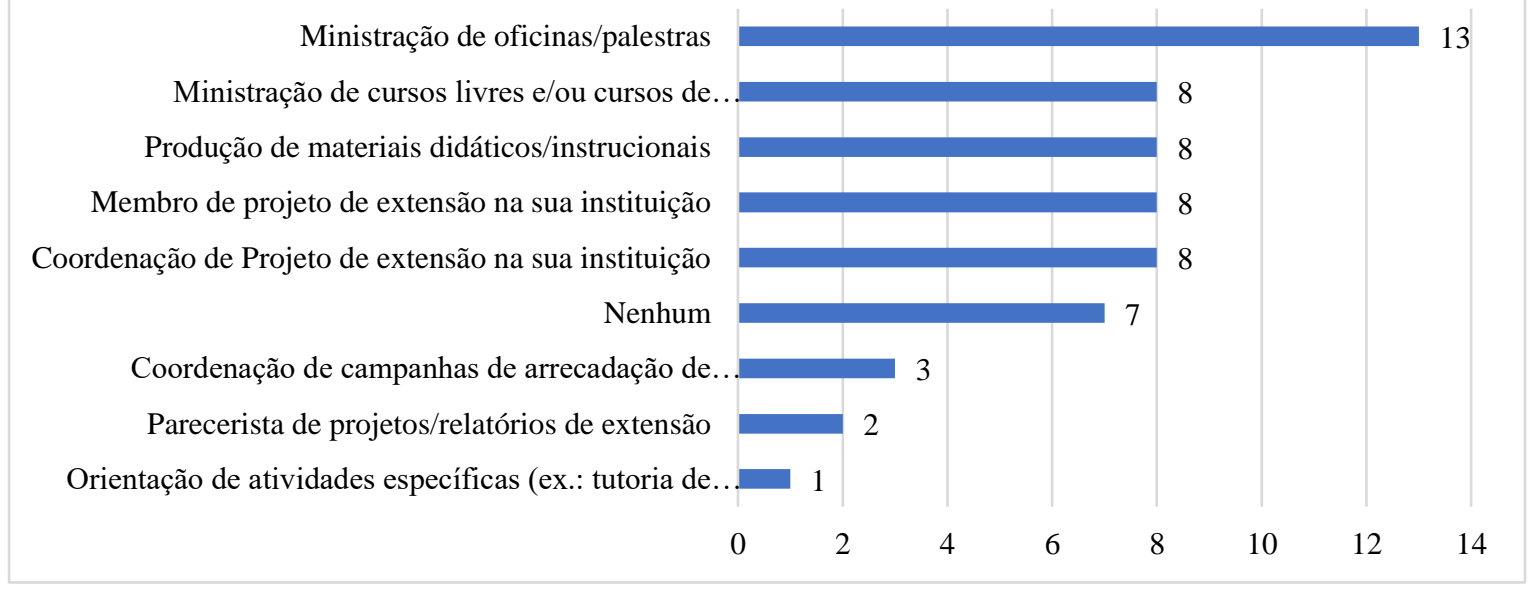

Fonte: dados da pesquisa (2020).

${ }^{1}$ Programa Institucional de Bolsas de Iniciação Científica (PIBIC) / Programa Institucional Voluntário de Iniciação Científica (PIVIC)

Revista Expectativa, Toledo/PR, v.20, n. 2, p. 90-115, abr./jun., 2021. 
Por fim, os docentes indicaram o seu envolvimento na gestão universitária, de modo que o gráfico 6 apresenta que 10 docentes não ocupam nenhum cargo de gestão, enquanto 9 participam como conselheiro/a em órgãos colegiados (conselhos, colegiados, congregações), seguido de 6 docentes que participam como membro/presidente de comissões instituídas pela administração.

Gráfico 6 - Atividades desenvolvidas na gestão

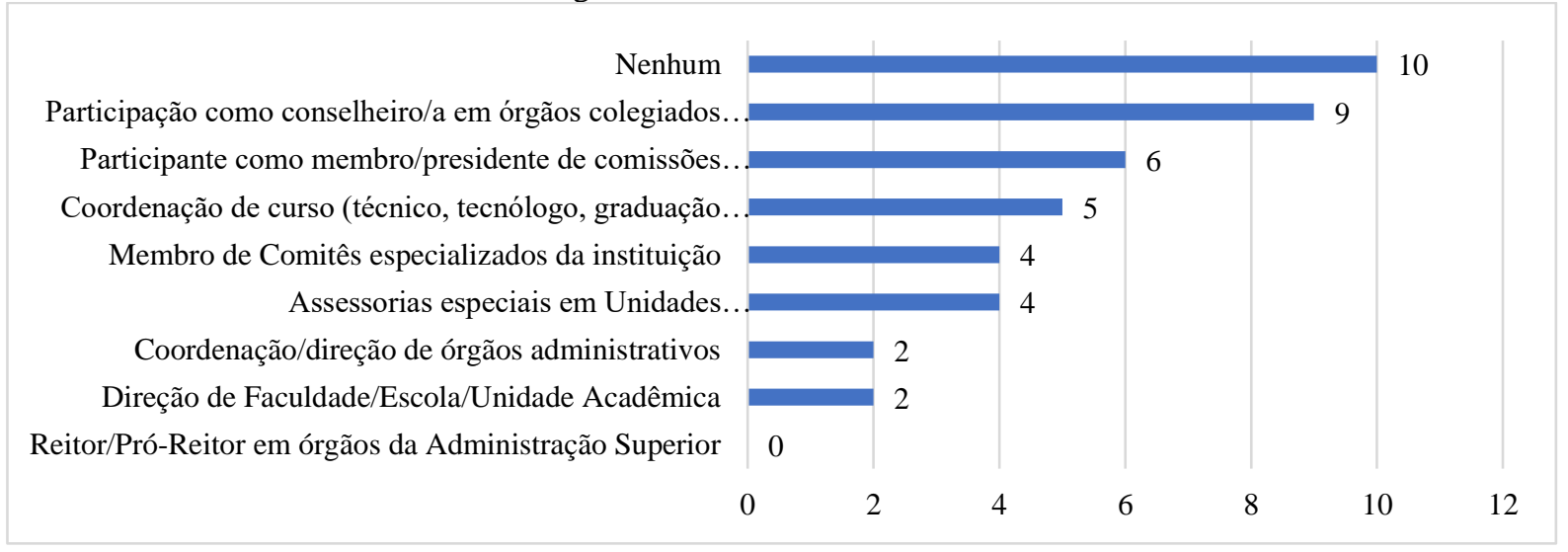

Fonte: dados da pesquisa (2020).

O professor, ao atuar como um gestor na atividade, não deixa de ser professor e, em muitos casos, desempenham elas simultaneamente. Porém, em alguns cargos e/ou funções, o professor precisa deixar de dar aulas para se dedicar aos ofícios da gestão, mas ele pode continuar envolvido com pesquisa ou com extensão.

os papéis de trabalho do professor na universidade que tradicionalmente englobavam pesquisa, extensão e ensino (com a divisão de trabalho tomando como base a especialização do campo de conhecimento) foram ampliados de forma que esses indivíduos atualmente também são levados a se concentrar na gestão, dentro de outra lógica de divisão de trabalho (BARBOSA; MENDONÇA, 2014, p. 135).

Quando um professor assume cargo de gestão na universidade, a comunidade espera que ele possua "competências gerenciais que lhes permitam alinhar o conhecimento técnico ao administrativo, além de habilidades de negociação e análise do contexto econômico, político e social” (MIRANDA, 2010, p. 13). Nesse contexto, o desempenho de alguns professoresgestores, às vezes, pode não ser tão profissionais, pois, na verdade, "esses profissionais têm à docência como carreira, além do fato de que a universidade federal, na maioria dos casos, não 
tem uma cultura de treinamento de seus atuais ou futuros dirigentes" (CAMPOS et al., 2008, p. 1).

Em seguida, e considerando a expressiva necessidade de produção e revisão documental das ações propostas de ensino, pesquisa, extensão e gestão, o gráfico 7 apresenta as respostas sobre o desejo dos professores adquirirem assessoria para lhes auxiliar nas atividades acadêmicas. Dos respondentes, 14 docentes alegaram que gostaria de receber assessoria, enquanto 11 disseram que talvez tivessem esse desejo.

Gráfico 7 - Desejo de ter uma assessoria para auxílio nas atividades acadêmicas

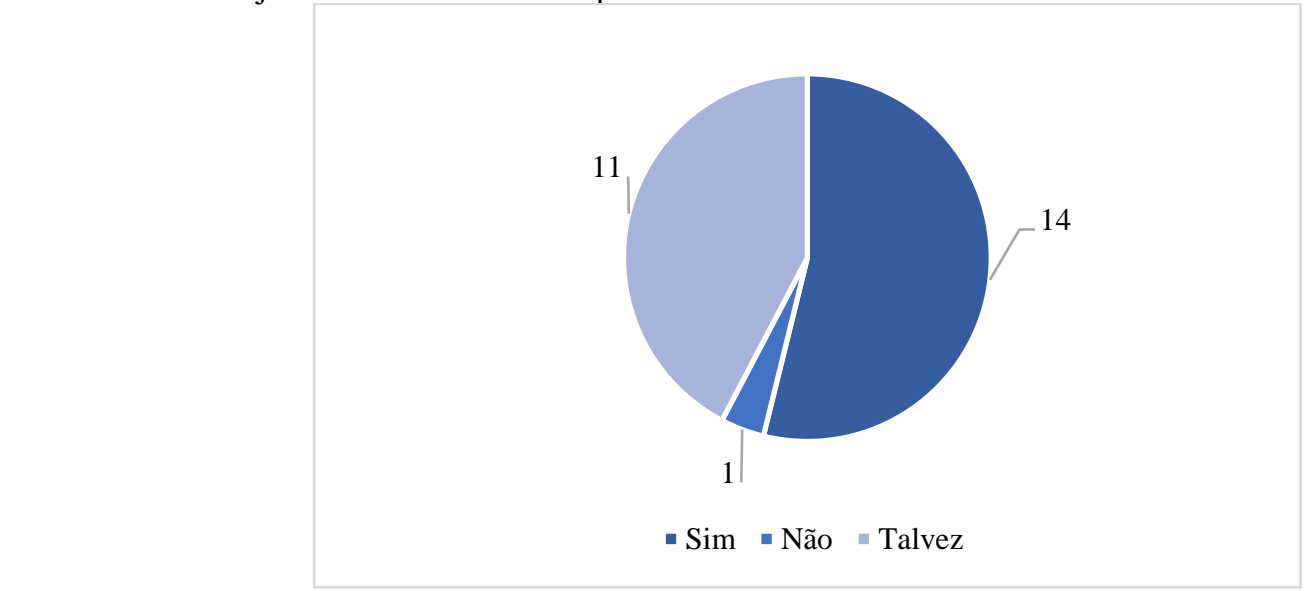

Fonte: dados da pesquisa (2020).

Especula-se que esse alto índice sobre "talvez" desejar uma assessoria porque os docentes talvez não tivessem refletido que uma assessoria pudesse ser possível, além da possibilidade de eles já terem se adaptado a forma e às demandas de trabalho na sua jornada. Ainda assim, é um fator que merece destaque, uma vez que é um percentual alto de docentes que podem reconsiderar a necessidade de uso de uma assessoria remota/virtual nas demandas universitárias. Concordando com Abreu et al. (2019) e Souza, Moreira e Martins (2018), há uma certa resistência/barreira cultural no oferecimento de prestação de serviços de assessoria remota, o requer do profissional secretarial virtual uma intensa divulgação e presença dos seus serviços junto à comunidade universitária, para ganhos progressivos de credibilidade junto ao público-alvo, o que, considerando os objetivos deste trabalho, se aplica ao contexto universitário.

Observa-se a presença da resistência/barreira cultural no gráfico 8, já que 14 docentes disseram que talvez necessitariam contratar uma assessoria remota para as atividades acadêmicas, enquanto 5 dos respondentes descartam a necessidade. Por outro lado, há 
possibilidades de oferecer serviços de assessoria remota às demandas acadêmicas, uma vez que 7 dos docentes afirmaram ter necessidade de contratação de serviços dessa natureza. Essa amostra apresenta o indicativo de um nicho de assessoria remota que pode ser captado pelos profissionais de Secretariado Executivo.

Gráfico 8 - Necessidade dos professores em contratar assessoria remota

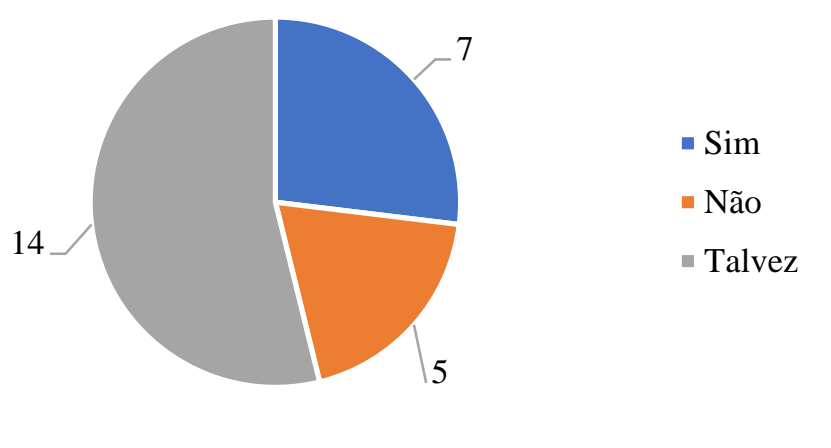

Fonte: dados da pesquisa (2020).

Em prosseguimento à análise de perspectivas e necessidades para a contratação dos serviços de assessoria remota acadêmica, no gráfico 9 têm-se as respostas sobre a possibilidade real dos professores contratarem um assistente remoto. Utilizando a escala de valores, eles apontaram sua necessidade em 1 que é uma possibilidade mínima de ocorrer a contratação e 5 a máxima.

Em uma perspectiva e, corroborando com as análises dos gráficos anteriores, 14 docentes disseram que existe a possibilidade de contratação de um/a assistente remoto, de acordo com as escalas 2 e 3 . Todavia, 9 professores já acenaram como possibilidade máxima e concreta a contratação de um assistente remoto (escalas 4 e 5), o que já revela uma abertura para a aceitação de uma assessoria virtual para as demandas acadêmicas. Porém, 3 dos respondentes ainda não consideram a possibilidade de contratar um assistente remoto, sendo as chances mínimas.

Revista Expectativa, Toledo/PR, v.20, n. 2, p. 90-115, abr./jun., 2021. 
Gráfico 9 - Possibilidade real de contratar um assistente remoto

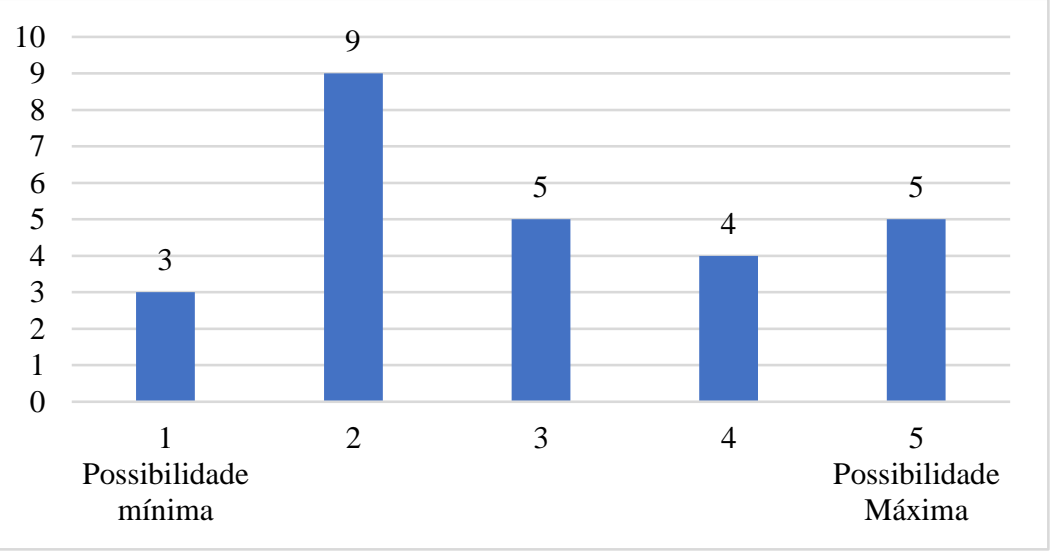

Fonte: dados da pesquisa (2020).

Devido às atividades múltiplas de docência universitária compreendida pelos quatro eixos e, considerando que a totalidade dos docentes exercem atividades de ensino e pesquisa, há uma probabilidade alta de contratação de serviços de assessoria remota, para organização de atividades e projetos propostos.

Nesse sentido, perguntou-se quais atividades os docentes gostariam de delegar ao assessor remoto, em que puderam selecionar mais de uma opção como resposta. O gráfico 10, exposto a seguir, explana as principais ocorrências:

Gráfico 10 - Atividades que poderiam ser delegadas ao assistente remoto

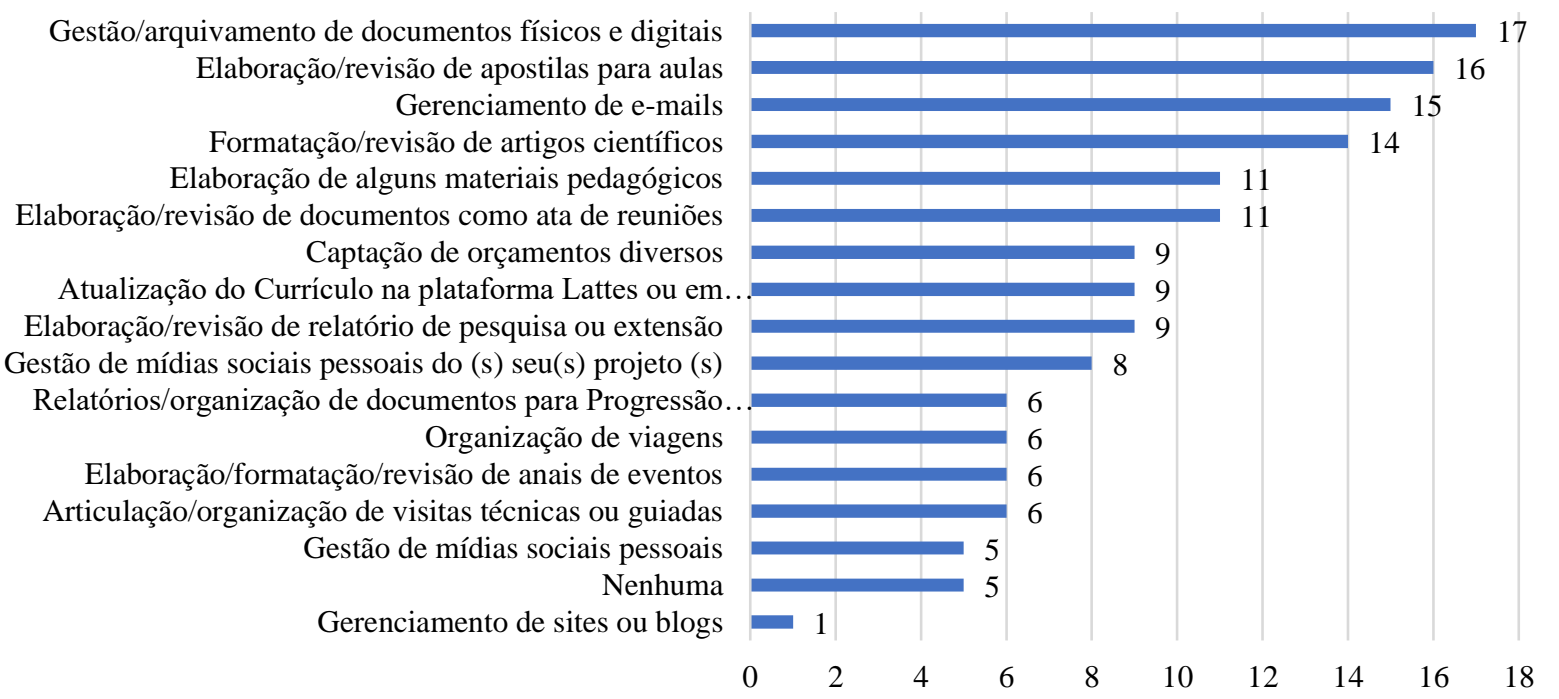

Fonte: dados da pesquisa (2020).

Revista Expectativa, Toledo/PR, v.20, n. 2, p. 90-115, abr./jun., 2021. 
Enumera-se as principais atividades por ordem relativa: a) gestão/arquivamento de documentos físicos e digitais (17); b) elaboração/revisão de apostilas para aulas (16); c) gerenciamento de e-mails (15); d) formatação/revisão de artigos científicos (14); e) elaboração de alguns materiais pedagógicos e f) elaboração/revisão de documentos como ata de reuniões (11), o que reflete que as competências comunicacionais, informacionais e redacionais do secretariado são necessárias e muito demandadas na prestação de serviço remoto aos docentes.

Dessas atividades, duas referem-se à organização necessária para atuação do professor: Gestão/Arquivamento de documentos físicos e digitais e gerenciamento de e-mails. Paes e Santiago (2019) destacaram que gerenciamento de e-mails e gestão e arquivamento de documentos físicos e digitais estão entre os serviços burocráticos e de secretaria mais oferecidos entre os escritórios virtuais secretariais, no que também se percebe a demanda forte entre os serviços acadêmicos que podem ser oferecidos aos docentes universitários.

Agora, há também serviços específicos que foram bastante destacados entre as respostas, atividades relacionadas ao ensino com a elaboração/revisão de apostilas para aulas; elaboração de alguns materiais pedagógicos, o que poderá demandar capacitações específicas para melhor oferecimento de serviços acadêmicos pedagógicos.

Uma atividade refere-se à pesquisa cientifica desenvolvida pelo professor que é a formatação/revisão de artigos científicos. Considerando que $80,8 \%$ dos docentes pesquisados exercem atividades ligadas à pesquisa nas instituições de ensino, em que os produtos oriundos da pesquisa se caracterizam notadamente por produção e publicação de artigos, resumos, projetos e relatórios de pesquisa em eventos ou periódicos científicos, ratifica-se a oportunidade para a prestação deste serviço no contexto acadêmico aos docentes.

Outra atividade, dessa vez ligada à gestão, é a elaboração/revisão de documentos como ata de reuniões. Aqui, pode-se abrigar prioritariamente a revisão de documentos administrativos, principalmente os mais complexos (como atas de reuniões), já que a elaboração é uma atribuição obrigatória dos técnicos-administrativos em educação (nas instituições federais), ou agentes administrativos (nas instituições estaduais) de acordo com o seu cargo e setor demandado. Até mesmo dos docentes que ocupam funções gerenciais/gratificadas/de coordenação, elaboração de documentos passa-se constituir como atribuição obrigatória, podendo ser delegado serviços de revisão quando precisar.

Por outro lado, as atividades menos apontadas foram o gerenciamento de sites ou blogs (1); articulação/organização de visitas técnicas (6); relatórios/organização de documentos para 
progressão funcional (6); gestão de mídias sociais pessoais (5). No entanto, essas atividades podem ser exploradas e divulgadas para que o docente queira se envolver com elas e, com isso, sentir a necessidade de assessoria remota.

Visando que essa pesquisa científica gere informações mais fidedignas possíveis para os profissionais que atuam como assistente remoto, perguntou-se aos professores o quanto que eles estavam dispostos a pagar por cada serviço, dentro do leque de serviços elencados no gráfico 6. Dessa forma, o gráfico 11 traz valores que vão de $\mathrm{R} \$ 0,00$ (zero reais) a $\mathrm{R} \$ 1.000,00$ (mil reais), o que reflete uma mínima necessidade de estruturação de quadros/tabelas de serviços com os valores exatos.

Gráfico 11 - Média de valor que o professor está disposto a pagar por cada serviço prestado

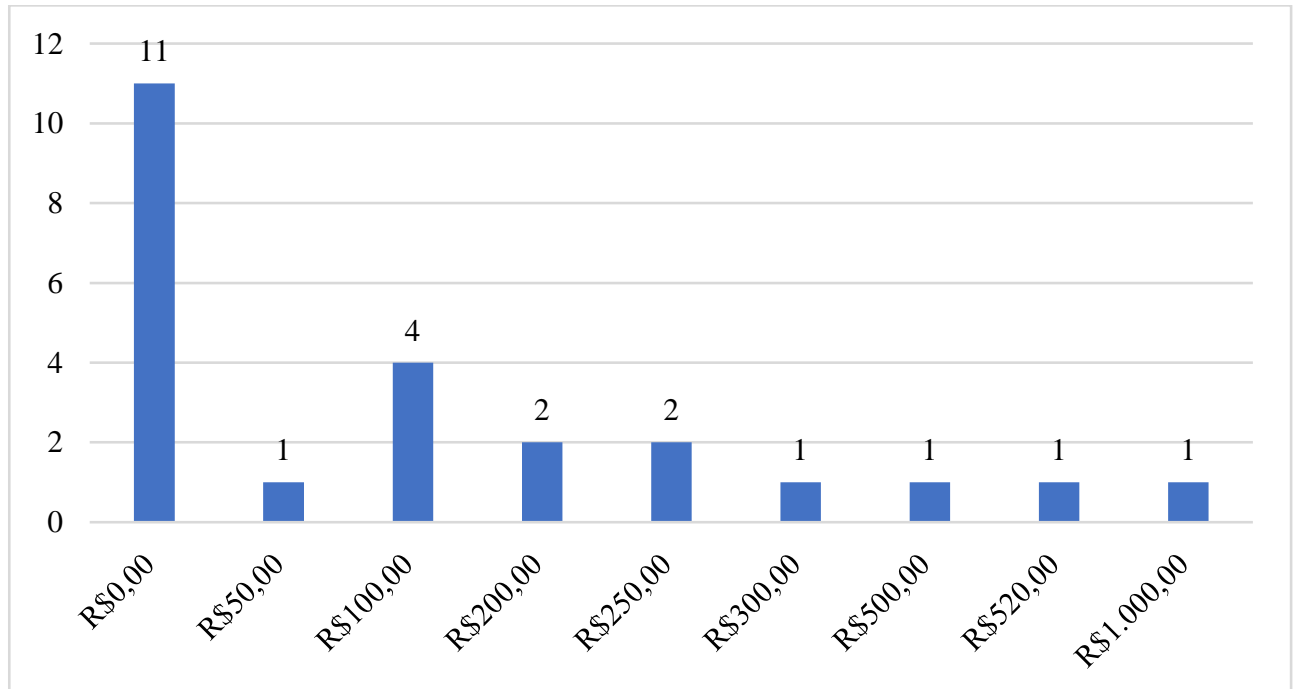

Fonte: dados da pesquisa.

Costa, Chizzoni e Vaz (2019), em pesquisa com uma profissional do assessoramento remoto, indicam que os ganhos podem variar entre $\mathrm{R} \$ 2.000,00$ (dois mil reais) a $\mathrm{R} \$ 5.000,00$ (cinco mil reais), provavelmente, mensais. Porém, possivelmente, os valores são considerados somados os serviços prestados durante um período (não estando especificado se é durante um mês ou por serviço prestado durante o estudo), o que leva à necessidade de definição de valores considerando diversas variáveis, a exemplo de estudos de consultoria: por período ou por atividade, de acordo com o serviço prestado. 


\section{CONSIDERAÇÕES FINAIS}

Modelos recentes de trabalho (ou mais conhecidos de acordo com a realidade brasileira) flexíveis ou virtuais estão sendo abordados e demonstrados em suas aplicações e práticas, especificamente na realidade secretarial. Diante disso, o objetivo geral da pesquisa verificou a necessidade que os docentes têm por um assessoramento remoto para auxiliar nas suas atividades acadêmicas e administrativas, já que consideram ter essa necessidade. Para os sujeitos que têm dúvidas sobre a sua necessidade de uma assessoria remota, cabe um investimento por parte dos assistentes virtuais para divulgar e mostrar a real contribuição dessa prestação de serviço, visando conquistar esses potenciais clientes.

Como objetivo específico, investigou-se as atividades que são realizadas pelos docentes universitários no quadripé universitário, sendo constatado o envolvimento deles com o ensino, a pesquisa, a extensão e a gestão. Conforme os dados apresentados, os docentes estão mais envolvidos com as atividades ligadas ao ensino, seguido de pesquisa e, em menor proporção, ocupam cargos de gestão.

Em seguida, verificou-se as atividades específicas eles desenvolvem no ensino, pesquisa, extensão e gestão. No ensino: aulas de graduação e orientação de estágio supervisionado; e projetos de monitoria. Na pesquisa: orientação de TCC; orientação/autoria de artigos para publicação em anais de eventos e periódicos; e membro de grupo de pesquisa. $\mathrm{Na}$ extensão: ministrando oficinas, palestras; produzindo materiais didáticos; e atuando nos projetos de extensão como coordenadores ou apenas membros. Na gestão: participam como conselheiro/a em órgãos colegiados (conselhos, colegiados, congregações); participante como membro/presidente de comissões instituídas pela administração; e coordenam curso (técnico, tecnólogo, graduação ou pós-graduação).

Por fim, mapeou-se os serviços que podem ser prestados aos docentes universitários por meio de assessoria virtual, de modo que foi possível elencar os cinco serviços mais demandamos pelos docentes para uma possível contratação de assessoria virtual: 1) Gestão/Arquivamento de documentos físicos e digitais; 2) elaboração/revisão de apostilas para aulas; 3) gerenciamento de e-mails; 4) formatação/revisão de artigos científicos; 5) elaboração de alguns materiais pedagógicos.

O presente estudo contou com algumas limitações: a) não pode ser generalizável, devido à amostra pequena (apenas 26 professores responderam ao questionário) de um universo

Revista Expectativa, Toledo/PR, v.20, n. 2, p. 90-115, abr./jun., 2021. 
desconhecido; b) a pesquisa necessita de um tempo maior, para possibilidades de confirmação da frequência dos serviços e generalização dos resultados, e c) pouca literatura que evidencie os serviços prestados no secretariado remoto para os docentes universitários, bem como as inovações em torno desta temática, já que estudos ainda são recentes.

Diante do retrato oferecido pela pesquisa, sugerem-se as seguintes propostas futuras: a) estudos quantitativos sobre os serviços de assessoramento virtual que podem ser oferecidos aos docentes universitários; b) pesquisas aprofundadas de mercado com profissionais que prestam serviços acadêmicos, para estimativas mais aproximadas de valores cobrados; c) verificação de profissionais de secretariado que já trabalhem com assessoramento virtual acadêmico.

\section{REFERÊNCIAS}

ABREU, B. M.; CASTRO, L. P.; LIMA, L. C.; SOUZA, E. C. P. As diferentes modalidades de trabalho no cotidiano secretarial: trabalho virtual versus modelo tradicional de assessoria. Refas - Revista Fatec Zona Sul, São Paulo, v. 5, n. 3, p. 25-41, fev./maio. 2019.

BARBOSA, M.; MENDONÇA, R. O Professor-Gestor em Universidades Federais: alguns apontamentos e reflexões. Teoria e Prática em Administração, v.4, n. 2, p. 131-154, 2014.

BARDIN, L. Análise de conteúdo. São Paulo: Edições 70, 2011.

BARROS, C. M. P; VASCONCELOS, L. S.; SILVA, J. S.; BRITO, D. G. S.; SILVA FILHO, M. C. virtualidade no mundo do trabalho: um estudo sobre a atuação do secretário executivo virtual. Revista Expectativa, v. 11, n. 11, p. 59-82, 2012.

BLEYER, L. K. Home-office: uma nova tendência na Administração. Revista de Ciências da Administração, v. 1, n. 2, p. 97-98, 1999.

BOZU, Z. El profesorado universitario novel: estudio teórico de su proceso de inducción o socialización profesional. Revista Electrónica de Investigación y Docencia, Jaén, España: Universidad de Jaén, n. 3, p. 55-72, enero/jun. 2010.

BRASIL, R. F. D. Dispõe sobre o estágio de estudantes. Planalto Lei $\mathbf{N}^{0} \mathbf{1 1 . 7 8 8}$, Brasília, 25 setembro 2008. Disponível em: http://www.planalto.gov.br/ccivil_03/_ato20072010/2008/lei/111788.htm. Acesso em: 28 nov. 2020.

BRASIL, Conselho Nacional de Desenvolvimento Científico e Tecnológico. Manual do Usuário do PIBIC/CNPq. Mimeo. Brasília, 1998. 
BRASIL. Constituição Da República Federativa Do Brasil De 1988. Disponível em: http://www.planalto.gov.br/ccivil_03/constituicao/constituicao.htm. Acesso em: 07 fev. 2021.

BRIDI, J. C. A. A Iniciação Científica na formação do universitário. Dissertação (Mestrado em Educação) - Universidade Estadual de Campinas, Campinas, 2004.

CAMPOS, D. C. S. et al. Competências Gerenciais Necessárias aos Professores-Gerentes que Atuam em Pró-Reitorias: o caso de uma Instituição Federal de Ensino Superior de Minas Gerais. In: ENCONTRO DA ENANPAD, XXXII, 2008, Rio de Janeiro. Anais [...]. Rio de Janeiro: Anpad, 2008.

CONCEIÇÃO, C.; SOUSA, O. Ser professor hoje. O que pensam os professores das suas competências. Revista Lusófona de Educação, v.20, n.20, p.81-98, maio/ago. Lisboa, 2012.

COSTA, T. P.; CHIZZONI, C. de C.; VAZ, C. de F. M. Secretários remotos ou in company: como se apresenta o mercado remoto para os profissionais de secretariado? Secretariado Executivo em Revist@, v. 15, n. 1, p. 62-76, 2019.

CRESWELL, J. W. Projeto de pesquisa: métodos qualitativo, quantitativo e misto. 2. ed. Porto Alegre: Artmed, 2007.

DELLAGNELO, E. L.; SILVA, C. L. M. Novas formas organizacionais: onde se encontram as evidências empíricas de ruptura com o modelo burocrático de organizações? Organ. Soc., Salvador, v. 7, n. 19, p. 19-33, set./dez. 2000.

ENUMO, S. R. F. Ensinar, pesquisar e fazer extensão universitária: missão (im)possível. Temas psicol., Ribeirão Preto, v. 4, n. 1, p. 79-95, abr./jun. 1996.

ENS, R. T.; DONATO, S. P. Ser professor e formar professores: tensões e incertezas contemporâneas. In: ENS, R. T.; BEHRENS, M. A. (Orgs.). Ser professor: formação e os desafios na docência. Curitiba: Champagnat, 2011. p. 79-100.

FANZERES, N.; LIMA, L. Evidências da Adaptação de Profissionais de Secretariado ao Trabalho Virtual. Revista de Gestão e Secretariado, São Paulo, v. 9, n. 1, p. 42-64, jan./abr. 2018.

FEIXAS, M. El profesorado novel: Estudio de su problemática en la Universitat Autónoma de Barcelona. Revista de Docencia Universitaria, Murcia, España: Universidad de Murcia, v. 2, n. 2, abr./jul. 2002.

FELDKERCHER, N. As relações entre uma jovem professora universitária iniciante na carreira docente e seus alunos de graduação. Revista Reflexão e Ação, Santa Cruz do Sul, v. 21, n. esp., p.128-148, jul./dez. 2013.

FREIRE, P. Pedagogia da autonomia: saberes necessários à prática educativa. 28. ed. São Paulo: Paz e Terra, 2003.

Revista Expectativa, Toledo/PR, v.20, n. 2, p. 90-115, abr./jun., 2021. 
FREIRE, P.; HORTON, M. O caminho se faz caminhando: conversas sobre educação e mudança social. 4 ed. Petrópolis-RJ: Vozes, 2003.

GONÇALVES, J. A. M. A carreira das professoras do ensino primário. In: NÓVOA, A. (Org.). Vida de professores. Lisboa: Porto Editora, 1999, p. 141-169.

LIBÂNEO, J. C. Reflexividade e formação de professores: outra oscilação do pensamento pedagógico brasileiro? In: PIMENTA, S. G.; GHEDIN, E. (Orgs.). Professor reflexivo no Brasil - gênese e crítica de um conceito. São Paulo: Cortez, 2002.

MARREIROS, A. V., SANTOS, F. T. F. dos, VIANA, I. A. F.,; RICHENE, W. C. F. Escritório Virtual no Amapá: nicho de mercado para secretário executivo. In: CONGRESSO NACIONAL DE SECRETARIADO, 19, Brasília, 2016. Anais [...]. Brasília, DF: 2016. Disponível em: https://fenassec.com.br/anais-do-xix-congresso-nacional-de-secretariado.pdf. Acesso em: 14 dez. 2020.

MARQUES, W. Ensino, Pesquisa e Gestão Acadêmica na Universidade. Avaliação, Campinas; Sorocaba, SP, v. 16, n. 3, p. 685-701, ago./nov. 2011.

MAZZILLI, S. Notas sobre o trabalho docente no ensino superior num projeto de universidade socialmente referenciada. Revista Leopoldianum, Santos, ano 31, n. 83-84-85, p. 145-156, jan./dez. 2005.

MELLO, Á. Teletrabalho (Telework): O Trabalho Em Qualquer Lugar E A Qualquer Hora. 1999. Disponível em: https://crasp.gov.br/wp/wpcontent/uploads/17_11_2004_teletrabalho_o_trabalho_em_qualquer_lugar_e_a_qualquer_hor a.pdf. Acesso em: 20 dez. 2020.

MENDES, T. C.; BACCON, A. L. P. Profissão docente: o que é ser professor? Disponível em: https://docplayer.com.br/64177270-Profissao-docente-o-que-e-ser-professor.html. Acesso em: 16 jan. 2021.

MENDONÇA, B. T.; CAMPOS, N. V.; SOUSA, R. F. R. de. A assessoria virtual como possibilidade de atuação para o profissional de secretariado executivo. In: ENCONTRO DE ESTUDOS E PESQUISAS EM SECRETARIADO EXECUTIVO - ENEPES, 2., 2017. Fortaleza. Anais [...]. Fortaleza, CE: UFC, 2017. Disponível em: https://docs.wixstatic.com/ugd/b43479_7c64bc30e84e4229979bede0f594a91e.pdf. Acesso em: 23 jul. 2020.

MIRANDA, A. R. A. Um estudo sobre a dinâmica identitária de professoras gerentes de uma universidade pública. Dissertação (Mestrado em Administração) - Universidade Federal de Lavras Minas Gerais, 2010.

MOITA, F. M. G. S. C.; ANDRADE, F. Ensino-pesquisa-extensão: um exercício de indissociabilidade na pós-graduação. Revista Brasileira de Educação, v. 14, n. 41, p. 269280, maio/ago. 2009.

Revista Expectativa, Toledo/PR, v.20, n. 2, p. 90-115, abr./jun., 2021. 
NONATO JÚNIOR, R. Epistemologia e Teoria do conhecimento em Secretariado Executivo: a Fundação das Ciências da Assessoria. Fortaleza: Expressão Gráfica, 2009.

NÓVOA, A. O passado e o presente dos professores. In: NÓVOA, A. (Org.). Profissão Professor. Lisboa: Porto Editora, 1999, p. 13-34.

NUNES, A. L. P. F; SILVA, M. B. C. A extensão universitária no ensino superior e a sociedade. Mal-Estar e Sociedade, Ano IV - n. 7, Barbacena, p.119-133, jul./dez., 2011.

PAES, R. V. O.; RODRIGUES, J. M.; OLIVEIRA, P. E. S. Canais online de comunicação sobre o secretariado: um mapeamento introdutório de perfis no Instagram. Revista de Gestão e Secretariado, São Paulo, v. 10, n. 3, p. 27-52, set./dez. 2019.

PAES, R. V. O.; SANTIAGO, C. S. Assessoramento remoto por meio de escritórios virtuais: uma categorização de serviços prestados. Revista Gestão e Secretariado (GeSec), São Paulo, SP, v. 11, n. 1, p. 41-62, jan./abr., 2020.

PERRENOUD, P. Dez Novas competências para Ensinar. Porto Alegre: Artmed Editora, 2000 .

SILVA, T. Perspectiva da atuação do secretário executivo como nova forma organizacional. Trabalho de Conclusão de Curso (Curso de Secretariado Executivo) Universidade Federal da Paraíba, Mamanguape, 2019.

SILVA, J. F.; SANTIAGO, C. S.; PAES, R. V. O. As práticas da assessoria através do escritório virtual. p. 129-144. In: CONGRESSO INTERNACIONAL DE SECRETARIADO, 4., São Paulo. Anais [...]. São Paulo, SP: Sinsesp, 2017. Disponível em: https://coins.com.br/wp-content/uploads/2018/05/Trabalho-21.pdf. Acesso em: 12 dez. 2020.

SOUZA, T.; MOREIRA, K. D.; MARTINS, C. B. TELETRABALHO: Um Segmento de Atuação para o Profissional de Secretariado. Revista Perspectivas Contemporâneas, v. 13, n. 1, p. 1-17, jan./abr. 2018.

TOZETTO, S. S. Trabalho docente e suas relações com o saber. In: TOZETTO, S. S. Trabalho docente: saberes e práticas. Curitiba: CRV, 2010.

VALÉRIO, A. B; TELES JÚNIOR; A. P.; VIANA, I. A. F.; MELLO, S. G. Escritório Virtual: análise de viabilidade econômica e financeira de implantação em Macapá-PA, sob a atuação do secretário executivo. p. 114-130. In: ENCONTRO NACIONAL DOS ESTUDANTES DE SECRETARIADO, VIII. Anais [...]. Florianópolis, SC: UFSC, 2016. 